\title{
ОРГАНІЗАЦІЯ ПРОФЕСІЙНОГО РОЗВИТКУ ПЕДАГОГІЧНИХ ПРАЦІВНИКІВ ДОШКІЛЬНИХ ЗАКЛАДІВ УРСР (60-70-ТІ РОКИ ХХ СТОЯІТТЯ)
}

Статтю присвячено висвітленню історико-педагогічного аспекту розвитку професійного рівня педагогічних праццівників закладів дошкільної освіти Украӥни. Схарактеризовано основні події означеного періоду, впродовж якого відбувався активний розвиток підвищення кваліфікації та трансформація змістової складової післядипломної освіти педагогічних працівників.

Визначено, ще у досліджуваний період післядипломна освіта педагогічних працівників дошкільної галузі набула активного розвитку, починаючи з 60-тих років ХХ століття, що обумовлено ьрунтовним нормативно-правовим забезпеченням організації та керівництва методичною роботою педагогічних кадрів.

Представлено огляд основних форм підвищення професійного розвитку педагогічних працівників, серед яких виділено курсову та семінарську перепідготовку, а також методичні та кущові об'єднання, школи передового педагогічного досвіду, народні університети й самоосвітню діяльність педагогів. Установлено, що такі форми роботи, як науковопрактичні конференції, педагогічні читання й педагогічні виставки також впливали на розширення знань у зазначеній галузі освіти.

На курсах перепідготовки педагогічних працівників увагу лекторів було звернено на висвітлення актуальних проблем марксистсько-ленінської теорії, педагогіки, психологї̈, теорії і практики навчально-виховної роботи дошкільного закладу, зокрема на засвоєння методичних аспектів організації освітнъого процесу з дітьми різних вікових груп.

Серед лекторів були кращці працівники дитячих закладів, працівники обласного відділу народної освіти, інституту удосконалення кваліфікації учителів, а також кращзі викладачі педагогічних училищ та вчителі шкіл міста. Організацією педагогічної практики займалися як методисти на громадських засадах, так і працівники кабінету дошкільного виховання інституту удосконалення квалібікацї̈ вчителів.

У досліджуваному хронологічному проміжку особливу увагу було приділено вивченню, узагальненню й розповсюдженню передового педагогічного досвіду, щзо констатувалося у всіх формах перепідготовки та підвищення кваліфікації.

Ключові слова: післядипломна освіта, підвищення кваліфікацїі, форми підвищення квалібікації, педагогічні працівники дошкільних закладів.

Постановка проблеми. Організація та розвиток змісту післядипломної педагогічної освіти особливої актуальності набуває на сучасному етапі розвитку освітньої галузі. Це пов'язано як зі змінами у системі підвищення кваліфікації, так із оновленням Базового компонента дошкільної освіти (Державного стандарту дошкільної освіти), який спрямовано на формування життевої компетентності дітей дошкільного віку, що визначається через сформованість наскрізних умінь.

*(C) Жорова I. Я.

*С Швед Г. В.

us 
Історико-педагогічний аналіз зазначеного часового проміжку також характеризується впровадженням новацій у змісті та організації удосконалення фахового рівня педагогів галузі дошкільної освіти, що обумовдюе актуальність дослідження історико-педагогічного досвіду й виокремлення позитивних тенденцій.

Аналіз досліджень. Особливості організації післядипломної освіти зазначеного історичного проміжку в дотичних до нашого дослідження напрямах досліджувади такі сучасні вітчизняні науковці, як В. Примакова, Н. Протасова, О. Самсонова, Г. Чух та ін. Проте питання форм і змісту післядипломної освіти педагогів дошкільної гадузі зазначеного хронологічного проміжку досліджено у наукових колах недостатньо, тому метою статті є аналіз шляхів розвитку підвищення професійного рівня педагогічних працівників дошкільних закладів УРСР у 60-70-х роках XX століття.

Виклад основного матеріалу. Активного розвитку післядипдомна освіта педагогічних працівників дошкільної галузі набуває, починаючи 3 60-тих років XX століття, що обумовлено грунтовним нормативно-правовим забезпеченням, яке регламентувадо організацію та керівництво методичною роботою педагогічних кадрів, зокрема «Положення про обласний інститут удосконалення кваліфікації вчителів» (1964р.), «Подоження про педагогічні кабінети на громадських засадах» (1964р.), «Положення про школи передового педагогічного досвіду УРСР» (1964р.), «Типове положення про районний (міський) кабінет» $(1968$ р.), «Положення про обласний (міський) інститут удосконалення вчителів» (1971р.) та ін. [10].

3 метою організації єдиної системи виховання дітей дошкільного віку, яка відповідала би вимогам досдіджуваного періоду, згідно постанови Центрадьного Комітету Комуністичної партії України та Ради Міністрів Української РСР від, 19 червня 1959 року № 949 «Про заходи по дадьшому розвитку дитячих дошкільних установ, поліпшенню виховання та медичного обслуговування дітей дошкільного віку» було прийнято рішення об'єднати два типи дитячих установ (ясла і дитячий садок) в єдину дошкільну дитячу установу. Поява об'єднаної дошкільної дитячої установи зумовила необхідність створення єдиної програми для виховання дітей 3 2-місячного віку і до вступу до школи. Внаслідок узагальнення теорії та практичного досвіду дошкільної галузі було прийнято «Програму виховання в дитячому садку» (1962 р.) та визначено зміст і форми роботи з дітьми дошкільного віку. Особливістю програми було виділення підготовчої групи та реалізація принципу наступності між дошкільною та початковою освітою.

На початку 60-х років кабінети дошкільного виховання при обласних інститутах удосконалення кваліфікації вчителів працювали над удосконаленням навчальновиховного процесу в дитячих садках відповідно до вимог нової Програми; поширенням й удосконаленням форм методичної роботи на громадських засадах; вивченням й упровадженням у роботу дитячих садків передового педагогічного досвіду.

Під час курсів підвищення кваліфікації, як і раніше, вивчали матеріали з'іздів КПРС, пленумів ЦК КПРС та ЦК КП України; новою ж складовою у змісті навчальних планів було ознайомлення з особливостями організації та роботи установи нового типу - об'єднаної дошкільної установи; методичні аспекти організації навчально-виховного процесу відповідно до вимог нової Програми виховання, зокрема завдання, зміст і принципи організації виховної роботи 3 дітьми різних вікових категорій, упровадження трудового виховання, а також питання підготовки дітей до школи. Слід відзначити поєднання теоретичної та практичної підготовки педагогів, про що свідчить виготовлення дидактичних посібників, іграшок-саморобок, виконання робіт із конструктивної та образотворчої діяльності під час практичних занять. Педагогічні 
працівники також знайомидися з матеріалами методичних кабінетів на громадських засадах, виготовдяли під керівництвом старших педагогів наочні посібники [8].

До читання лекцій на курсах традиційно залучалися кращі працівники дитячих садків, педагогічною практикою керувади громадські методисти, працівники кабінету дошкільного виховання інституту удосконалення кваліфікації вчителів.

Досліджуючи архівні джерела 70-х років, можна констатувати диференціацію у підходах до організації курсової перепідготовки різних категорій слухачів. Навчальні плани розподілялись окремо для вихователів, методистів, завідувачів дошкільних закладів [9].

Безумовно, така форма підвищення професійного рівня, як курси, не могла охопити велику кількість педагогічних працівників дошкільних закладів, тому для поліпшення теоретичної та практичної підготовки, розширення й погдиблення знань 3 організації навчально-виховної роботи проводидися семінари. Семінарською перепідготовкою, яка відбувалась на базі інститутів удосконалення кваліфікації вчителів, було охоплено різні категорії педагогічних працівників (керівники методичних об'єднань, завідувачі методичними кабінетами, методисти, інспектори на громадських засадах; завідувачі дитячих садків; музичні керівники; вихователі кодгоспних дошкільних установ). Як зазначалося у публікаціях 1975 року, щорічно кабінетом дошкільного виховання проводилося 8-9 постійно діючих семінарів 3 різних питань виховання і навчання дітей [6; 8].

У досліджуваний період продовжували працювати й методичні об'єднання, які допомагади педагогічним працівникам дитячих садків підвищувати рівень своїх фахових знань. Публікації того часу свідчать про підготовку й перепідготовку вихователів сільських ясел-садків за допомогою інституту підвищення кваліфікації вчителів та через районні (зональні) методичні об'єднання [2, с. 3]. Робота методичного об'єднання передбачала складання індивідуального плану роботи педагогів, визначення теми передового педагогічного досвіду, який пізніше вивчався й узагадьнювався на педагогічній нараді $з$ подальшим обговоренням на методичному об'єднанні [4, с. 23].

Аналізуючи наративні джерела 3 досліджуваного питання, слід зазначити, що активною формою вивчення, поширення і впровадження передового педагогічного досвіду стали кущові об'єднання (4-5 дитячих садків, об'єднаних територіально). Зміст роботи кущового об'єднання було спрямовано на вирішення загальних завдань дошкільних працівників району і міста, обмін і впровадження досвіду, що давало мождивість підвищити якість виховання у кожному дитячому садку [11, с. 31].

На особливу увагу заслуговує нова форма методичної роботи - школи передового педагогічного досвіду. Згідно Положення, такі школи організовувалися на базі кращих дитячих закладів. Високий рівень навчально-виховної роботи в опорних дитячих садках дав змогу проводити експериментальну роботу з різних питань виховання і навчання дітей [1, с. 47].

Як наслідок прийняття «Положення про педагогічні кабінети на громадських засадах» (1964р.), «Подоження про громадського методиста районного, міського, обласного ВНО та Міністерства освіти УРСР» (1964р.) розповсюдженими формами фахового зростання стали громадські новоутворення. На допомогу вихователям, завідувачам, методистам на громадських засадах кабінетом дошкільного виховання було розроблено інструктивний матеріал, а саме: примірний план роботи кабінету на громадських засадах, рекомендації щодо його обладнання, примірний план шкоди передового педагогічного досвіду для вихователів, завідувачів дитячих дошкільних установ, примірну тематику для роботи районних, кущових методичних об'єднань [8, арк. 6]. 
Особливу роль у підвищенні кваліфікації педагогічних працівників дошкільних закладів займала самоосвіта. Усі дошкільні працівники систематично підвищували рівень своїх знань за індивідуальними планами, які передбачади гдибоке вивчення питань теорії й практики дошкільного виховання, ознайомлення 3 новими працями 3 педагогіки, психодогії, гігієни, програмно-методичними документами. Можна сказати, що самоосвіта стала найбільш поширеною формою отримання й підвищення професійних знань педагогічними працівниками та здійснювалася за «Програмою самоосвіти завідуючих, методистів і вихователів дошкільних закдадів», розробленою Республіканським учбово-методичним кабінетом дошкільного виховання. Програма передбачала роботу з підвищення ідейно-політичного рівня, науково-теоретичну підготовку, підвищення педагогічної майстерності та загальнокультурного рівня. Вона була основою річних планів самоосвітньої роботи дошкільних працівників, які склададися на $4-5$ років [7].

Для поглибленої роботи, передусім із методистами і завідувачами, у 1968 році було організовано університет наукових знань для дошкільних працівників, а в 1969 році - створено дошкільний факультет при університеті наукових знань для вчителів. Тематика декцій визначалась новітніми досягненнями науки і техніки, зокрема питань дошкільної педагогіки та психології [3, с. 25].

Висновки. Під час аналізу підвищення професійного рівня педагогічних працівників дошкільних закладів УРСР у 60-70-х роках XX століття нами було визначено зміни у змісті навчальних планів, які були спрямовані на вирішення актуальних завдань досліджуваного періоду, а також форми підвищення кваліфікації, зокрема курсова та семінарська перепідготовка, методичні та кущові об'єднання, школи передового педагогічного досвіду, університети наукових знань та самоосвіта. Досягненням даного періоду було прийняття нормативно-правового забезпечення у галузі організації підвищення кваліфікації педагогічних кадрів, що зумовило появу нових форм і методів роботи $з$ підвищення професійних знань. Проте викликає сумнів невід'ємна політична складова у змісті навчальних планів, яка передбачала вивчення питань внутрішньої та зовнішньої політики партії, марксистсько-ленінської теорії.

Перспективи подальшого дослідження полягають у більш детальному вивченні історичного аспекту проблеми з метою виокремлення позитивних надбань даного хронологічного проміжку.

\section{Список використаних джерел:}

1. Абрамова $\Lambda$., Бурова $\Lambda$., Крушинська В. Опорні дитячі садки та школи передового педагогічного досвіду. Дошкільне виховання. 1969. № 1. С. 47-48.

2. Авдюхіна К. Робота з кадрами сільських дошкільних закладів. Дошкільне виховання. 1965. № 7. C. 3-9.

3. Ворвулєва М. Університет наукових знань. Дошкільне виховання. 1969. № 7. С. 25-27.

4. Лавриченко Н. Про роботу методичного об'єднання. Дошкільне виховання. 1963. № 2. С. 23-25.

5. Марушевська О. Зростає педагогічна майстерність наших кадрів. Дошкільне виховання. 1965. № 2. C. 20-24.

6. Мусіяченко Т. Система роботи з кадрами. Дошкільне виховання. 1975. № 2 . С. 39-43.

7. Нікітенко В. П. Постійно вдосконалювати кваліфікацію - обов'язок вихователя. Дошкільне виховання. 1972. № 10. С. 5-8.

8. Отчет о работе кабинета дошколького воспитания за 1963-1964 учебный год. Державний архів Херсонської області (ДАХО). Р-2419. Оп. 2. Спр. 183. 25 арк.

9. Учебно-тематические планы курсов на 1979 год. ДАХО. Ф. Р-2419. Оп. 2. Спр. 748. 95 арк.

10. ШведГ. Нормативно-правове забезпечення підвищення кваліфікації педагогічних працівників закладів дошкільної освіти у 60-70-х рр. XX ст. Вісник Національного університету 


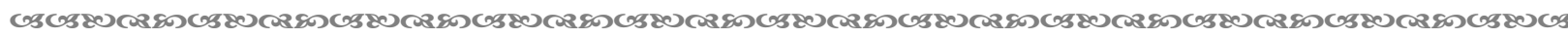
ПЕДАГОГІЧНИЙ АЛЬМАНАХ. - 2021. - ВИПУСК 50

US

«Чернігівський колегіум» імені Т. Г. Шевченка. Вип. 11 (167) / Національний університет «Чернігівський колегіум» імені Т. Г. Шевченка; голов. ред. М. О. Носко. Чернігів: НУЧК, 2020. C. 212-216.

11. Хмара Н. Кущові об’єднання. Дочкільне виховання. 1966. № 10. С. 31-33.

\section{References:}

1. Abramova, L., Burova, L., \& Krushynska, V. (1969). Oporni dytiachi sadky ta shkoly peredovoho pedahohichnoho dosvidu [Supporting kindergartens and schools of advanced pedagogical experience]. Doshkilne vykhovannia, 1, 47-48 [in Ukrainian].

2. Avdiukhina, K. (1965). Robota z kadramy silskykh doshkilnykh zakladiv [Work with the staff of rural preschools]. Doshkilne vykhovannia, 7, 3-9 [in Ukrainian].

3. Vorvulieva, M. (1969). Universytet naukovykh znan [University of Scientific Knowledge]. Doshkilne vykhovannia, 7, 25-27 [in Ukrainian].

4. Lavrychenko, N. (1963). Pro robotu metodychnoho obiednannia [About work of methodological association]. Doshkilne vykhovannia, 2, 23-25 [in Ukrainian].

5. Marushevska, O. (1965). Zrostaie pedahohichna maisternist nashykh kadriv [The pedagogical skills of our staff are growing]. Doshkilne vykhovannia, 2, 20-24 [in Ukrainian].

6. Musiiachenko, T. (1975). Systema roboty z kadramy [Human resources system]. Doshkilne vykhovannia, 2, 39-43 [in Ukrainian].

7. Nikitenko, V. P. (1972). Postiino vdoskonaliuvaty kvalifikatsiiu - oboviazok vykhovatelia [It is the educators' responsibility to constantly improve their skills]. Doshkilne vykhovannia, 10, 5-8 [in Ukrainian].

8. Otchet o rabote kabyneta doshkolkoho vospytanyia za 1963-1964 uchebnyi hod [Report on the work of the department of preschool education for the 1963-1964 school year] (Fund P-2419. Inventory 2. File 183). State Archive of Kherson region, Kherson [in Ukrainian].

9. Uchebno-tematycheskye plany kursov na 1979 hod [Curriculum for 1979] (Fund P-2419. Inventory 02. File 748). State Archive of Kherson region, Kherson [in Ukrainian].

10. Shved, H. (2020). Normatyvno-pravove zabezpechennia pidvyshchennia kvalifikatsii pedahohichnykh pratsivnykiv zakladiv doshkilnoi osvity u 60-70-kh rr. XX st. [Regulatory and legal support of in-service training of preschool educational institutions pedagogical staff in the USSR in the $60-70$ 's of the XX century]. Visnyk Natsionalnoho universytetu "Chernihivskyi kolehium» imeni T. H. Shevchenka, 11 (167), 212-216 [in Ukrainian].

11. Khmara, N. (1966). Kushchovi obiednannia [«Bush» associations]. Doshkilne vykhovannia, 10, 31-33 [in Ukrainian].

Zhrova I. Y., orcid.org/0000-0003-4304-4962

Shved H. V., orcid.org/0000-0002-7931-885X

\section{ORGANIZATION OF PROFESSIONAL DEVELOPMENT OF PEDAGOGICAL EMPLOYEES OF PRESCHOOL EDUCATIONAL INSTITUTIONS OF THE USSR (60-70S OF THE XX CENTURY)}

The article deals with the historical and pedagogical aspect of the development of the professional level of pedagogical employees of preschool educational institutions of Ukraine. The main events of this period are characterized, during which there was an active development of professional development and transformation of the content component of postgraduate education of pedagogical employees.

It is determined that in the studied period postgraduate education of preschool teachers has been actively developing since the 60s of the twentieth century, due to the legal support, which provided the organization and management of methodical work of teachers.

An overview of the main forms of professional development of teachers, including course and seminar retraining, as well as methodological and "bush" associations, schools of advanced pedagogical experience, public universities and self-educational activities. It is established that such 
forms of work as scientific and practical conferences, pedagogical readings and pedagogical exhibitions also influenced the expansion of knowledge in this field of education.

At the retraining courses for teachers, the lecturers focused on current issues of Marxist-Leninist theory, pedagogy, psychology, theory and practice of educational work of preschool, in particular on mastering the methodological aspects of the educational process with children of different ages.

Among the lecturers were the best employees of children's educational institutions, employees of the regional department of public education, the Teacher Training Institute, as well as the best teachers of pedagogical schools and teachers of schools in the city. Both methodologists on a voluntary basis and employees of the department of preschool education of the Teacher Training Institute were engaged in the organization of pedagogical practice.

In the studied chronological period, special attention was paid to the study, generalization and dissemination of advanced pedagogical experience, which was noted in all forms of retraining and advanced training.

Key words: postgraduate education, advanced training, forms of advanced training, pedagogical employees of preschool educational institutions.

Дата надходження статmі: 28.102021 .

Рецензент: доктор педагогічних наук, доцент Чумак $\Lambda$. В.

\author{
УДК 371.3(378) \\ DOI https://doi.org/10.37915/pa.vi50.324
}

Кузвменко В. В.", orcid.org/0000-0002-5424-8234

\title{
ПРОВІДНІ ТЕНДЕНЦІЇ РОЗВИТКУ ВІЙСЬКОВОЇ ОСВІТИ В УКРАЇНІ НА ПОЧАТКУ ХХІ СТОЛІТТЯ
}

У статті описано сучасний стан розвитку системи військової освіти в Украйні. Зазначено, що сьогодні вища військова освіти $є$ корпоративною системою підготовки військових, основне призначення яких полягае у виконанні професійних завдань у конкретних умовах. Звернуто увагу на те, щзо вища військова освіта надається у спеціалізованих закладах вищої освіти та військових навчальних підрозділах закладів вищой освіти.

Акцентовано, що останніми роками вектор розвитку військової освіти Украйни спрямовано на вступ у НАТО, інтеграцію в ЄС та приведення чинної системи до відповідних міжнародних стандартів. Зокрема, в Украӥні впроваджується проєкт «Професійна військова освіта», спрямований на вдосконалення системи військової освіти та ії законодавчої бази.

Висвітлено сутність та зміст спрощеної системи військової освіти, яка запроваджується сьогодні в Україні. Наведено приклади імплементації системи лідерських курсів у вищі військові заклади освіти держави (Військовий інститут телекомунікацій та інформатизації імені Героїв Крут, Національний університет оборони Украйни імені Івана Черняховського, Київський інститут Національної гвардї Украйни).

Виділено провідні тенденціӥ розвитку військової освіти в украйні на початку ХХІ століття: удосконалення чинної законодавчої бази, щз спрямована на інтеграцію світових стандартів та нарощування власних військових спроможностей; перехід на перспективну систему військової освіти, що передбачае припинення заочного навчання за держбюджетні кошти та уведення системи лідерських L-курсів на заміну існуючим; створення відповідних

*(C) Кузименко В. В.

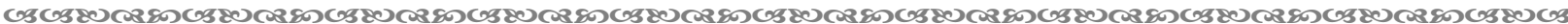
202 